\title{
PENSAMENTOS LINGUÍSTICOS E PRÁTICA TRADUTÓRIA PÓS-ESTRUTURALISMO E PSICANÁLISE COMO HORIZONTES À TRADUÇÃO
}

Guilherme Lima Cardozo é professor da Escola de Administração Judiciária (ESAJ), mestre em Estudos da Linguagem pela PUCRIO e doutorando em Estudos da Linguagem na PUC-RIO. E-mail: guilhermegoldenstein@ hotmail.com

\section{Resumo}

O objetivo deste artigo é apresentar de que forma a prática tradutória é vista no cenário global e os mitos que giram em torno do universo da tradução, bem como proporcionar um intercâmbio com as ideias pósestruturalistas, especialmente com a psicanálise, a fim de mostrar de que maneira diferentes pontos de vistas acerca do texto influenciam na forma de se enxergar a tradução.

\begin{abstract}
This article aims to show how translation practice is seen in the global scenario and the myths which revolve around the translation universe as well as provide an exchange with poststructuralism ideas, especially with psychoanalysis, in order to show how different points of view about text influence the way translation is viewed
\end{abstract}

\section{1) Introdução}

Neste trabalho faremos um intercâmbio entre textos os quais debatem acerca das peculiaridades da tradução, abordando diferentes pontos de vista sobre a complexidade deste ofício, bem como a crença comum de que traduzir não é uma tarefa tão difícil contanto que se tenha um bom dicionário à mão. Para tanto, tomaremos como base prismas diversos acerca da língua, como, por exemplo, o tradicional, o qual delimita a linguagem à função mor de representar e descrever as coisas do mundo - linguagem nomenclatura -, bem como o de língua como sistema, muito oportunamente desenvolvido por Ferdinand de Saussure, onde vislumbraremos dentro da langue não mais uma idiossincrasia independente, onde cada palavra possui positivamente um significado, mas uma rede de relações entre elementos de uma língua, os quais significam por essas relações. Ainda, traremos, superficialmente, o ponto de vista dos pós-estruturalistas no que concerne à prática tradutória, observando de que forma houve o corte epistemológico com as teorias tradicionais e como suas posições desconstrucionistas motivaram um novo olhar sobre a linguagem.

Começaremos por responder a algumas questões relativas à tradução, considerando a linguagem como forma de representação do mundo, sob a alcunha de língua-repertório, dialogando com as obras de Mounin, Levy e Simcovich, fazendo ponte com outros textos, como o de Paulo Britto e, naturalmente, o Curso de Saussure.

\section{2) As línguas como nomenclaturas}

Durante muitos séculos de estudos linguísticos, a teoria que predominou no que diz respeito à língua foi aquela compreendida sob o paradigma da representação, tal qual se apresenta no Crátilo de Platão, por exemplo, uma obra preponderante para a 
abordagem da língua como um fenômeno de nomeação das coisas do mundo. Lá, Platão desenvolve seu argumento sob o pálio de uma tese naturalista de linguagem, onde cada palavra possui sua essência, o seu significado próprio.

Essa visão será denunciada por Mounin ao se referir ao Crátilo, afirmando que tal obra serviu "para ilustrar o processo mental arcaico graças ao qual a atribuição de nomes às coisas (e de sentidos às palavras), era concebida como um batismo e como um recenseamento" (MOUNIN, 1975, p. 35). Essa concepção de língua como nomenclatura atua diretamente na noção de significado, pois, conforme já dissemos, cada palavra de uma dada língua possuirá o seu significado, independente de sua relação com as outras palavras ou com o contexto. A positividade das palavras será rechaçada por Mounin, e como fonte de suas argumentações, este cita Saussure, ao afirmar que suas análises abalaram a noção tradicional de língua: "se as palavras fossem incumbidas de representar conceitos dados de antemão, cada uma delas teria, de uma língua para outra, correspondentes exatos quanto ao sentido: ora, isto não acontece" (SAUSSURE apud MOUNIN, 1975, p. 31).

Tomando por base a noção de língua sob o prisma da representação, cada povo possuiria a sua nomenclatura cristalizada para determinados objetos, como por exemplo - e isso Mounin também cita em seu texto - para o francês, o animal cavalo seria denominado cheval, para o alemão, Pferd, para o inglês, horse, de forma que "as diferenças entre as línguas reduzir-se-iam a diferenças de designação (...) aprender uma segunda língua consistiria apenas em memorizar uma nova nomenclatura, ponto por ponto paralela à antiga" (MARTINET apud MOUNIN, 1975, p. 32). E aí retornamos à velha noção tradicional de língua, conforme escreveu Aristóteles em seu De Interpretatione, onde os sons emitidos pela fala são símbolos das afecções da alma, e as palavras são os símbolos dos sons emitidos pela fala; e apesar de fala e escrita não serem as mesmas em toda parte, as afecções da alma assim o são, como o são também os objetos dos quais essas afecções são representações (De Interpretatione, 16a 1).

\section{1) Traduzir é fácil?}

Há quem possa dizer que, por essas ideias remontarem a tempos muito remotos, não fazem mais parte do ideário social. Contudo, ainda faz parte do senso comum essa noção de língua-repertório, o que influencia diretamente na opinião que as pessoas possuem do ofício de traduzir, conforme Angela Levy cita em seu artigo Sabe inglês? Vire tradutor...: "Ouço sempre este comentário, dirigido a ex-estudantes de intercâmbio: "Você não aprendeu inglês? Então, por que não 'vira' tradutor? Deve ser fácil, e parece que dá um bom dinheirinho..."”. O professor Paulo Britto também atesta esse senso comum sobre o sentimento de que traduzir é fácil: 
As pessoas tendem a pensar (i) que traduzir é, na verdade, uma tarefa relativamente fácil; (ii) que o principal problema do tradutor consiste em saber que nomes têm as coisas num idioma estrangeiro; (iii) que este problema se resolve com a consulta de dicionários bilíngues (BRITTO, 2012, p. 12).

Esse senso comum acerca de língua como uma lista de nomes para as coisas resulta numa consequente visão distorcida do ofício do tradutor perante a sociedade, para a qual a língua, conforme Saussure denunciava em seu Curso, "reduzida a seu princípio essencial, é uma nomenclatura, vale dizer, uma lista de termos que correspondem a outras tantas coisas (...) Tal concepção é criticável em numerosos aspectos" (SAUSSURE, 2012, p. 105-106). Saussure nos queria mostrar que, nas palavras do professor Paulo Britto, a delimitação entre conceitos próximos, dentro de um mesmo campo semântico, se faz de modo diferente em línguas diferentes (BRITTO, 2012, p. 14).

Para suplantar essa visão do tradutor como um mero substituidor de palavras cujos sentidos são estáveis, é que Lawrence Venuti afirma em $A$ invisibilidade do tradutor que os tradutores não podem apenas servir de intermédio a uma obra original: devem se fazer visíveis, introduzindo nos textos passagens que surpreendam o leitor. Se dessa maneira não for, como querem ser bem remunerados? (BRITTO, p. 23). Na proposta de Venuti, é somente rompendo com os modelos tradicionais de linguagem - e também de tradução - que a profissão ganhará o espaço e o respeito merecidos dentro do mercado de trabalho. A ideia de que traduzir é fácil é resultado, segundo Simcovich, dessa invisibilidade que o tradutor possui, de certa forma imposta pela maneira como o profissional é visto no âmbito social: haja vista a noção dominante de língua como representação das coisas no universo, iguais em todo o mundo, o tradutor, como substituidor dos rótulos de uma língua para outra, torna-se vítima de desprestígio no mercado, marginalização profissional, o que acarreta em prazos irrisórios para realizar suas traduções e uma remuneração, conforme Venuti afirma, insatisfatória. E o pior é que, ao realizar o seu trabalho, dentro dos prazos estipulados por aqueles que compartilham o ideário comum do "traduzir é fácil", o próprio tradutor corrobora e reafirma esse mito.

Tanto nos comentários de Venuti, como nos de Rosemary Arrojo, abaixo, vemos que um traço pós-estruturalista se insurge nos meios de tradução, onde a objetividade plena começa a dar lugar a uma subjetividade pulsante, haja vista não ser mais possível - diríamos que nunca foi possível - uma neutralidade diante de um fato tradutório. Diante disso, Arrojo afirma:

[...] a questão teórica da tradução se destaca exatamente porque, devido a suas características peculiares, escancara problemas e questões que outros usos da linguagem podem mascarar mais facilmente. Nesse sentido, a tradução pode nos servir como um 
instrumento desconstrutor de proposições acerca da linguagem há muito estabelecidas e raramente discutidas (ARROJO, 2003, p. 72).

Para encerrar esta seção, concluímos que a noção de língua como instrumento de nomeação das coisas do mundo, nas palavras de Saussure, possuidora de significados universais, além de ser equivocada, conduz a uma crença infundada acerca da atividade tradutória como simplório transporte de palavras de uma língua à outra, como se houvesse um significado estável, fixo, imutável e a-histórico em cada significante, daí a afirmação saussureana de que "o significante é imotivado, isto é, arbitrário em relação ao significado, com o qual não tem nenhum laço natural na realidade" (SAUSSURE, 2012, p. 109), rejeitando-se a tese naturalista do Crátilo, onde significante e significado estariam ligados por uma relação interior à sequência de sons que determina o significante.

\section{3) Um corte na tradição}

Mounin, em sua obra já mencionada aqui, dedica um capítulo ao que ele chama de teorias neo-humboldtianas, onde se questionará a possibilidade de uma tradução "limpa" e "pura", colocando-se em xeque a ideia presente no ideário metafísico, de que as línguas poderiam ser operadas universalmente, haja vista a tese platônica, constante do Crátilo, de palavras portadoras de uma essência, resultado de sua vocação de representação das coisas do mundo e, conforme já citamos da obra de Aristóteles, as afecções da alma serem as mesmas em toda parte do mundo, por mais que a fala e a escrita variem em suas formas.

Não mais se enxergam as línguas como espelhos de um mundo ideal, com toda sua passividade de apenas representar um exterior. Conforme o próprio Mounin cita, tomando Humboldt como base, essa nova filosofia considerava a língua em seu princípio ativo, impondo ao pensamento um conjunto de valores e distinções - noção esta que observaremos com mais fulgor nas teorias saussureanas sobre o valor e a negatividade do signo -, refutando o modelo de língua como reprodução, através de nomenclaturas, das coisas do mundo, mas atribuindo-lhe uma função hermenêutica em relação ao universo. O autor, citando Max Müller, afirma que "a linguagem é o recurso através do qual os homens criam a sua concepção, sua compreensão e seus valores da realidade objetiva" (MOUNIN, 1975, p. 50), antecipando o que, mais à frente, os pósestruturalistas levantarão como bandeira: a potência demiúrgica da linguagem.

Essas teorias as quais ele associará a essa teoria neo-humboldtiana, vão de encontro ao pensamento tradicional, no concernente à concepção dos significados, pois há aqui a recusa da língua como mero instrumento passivo da expressão, consistente em termos positivos, significando em si alguma coisa. As noções de relação e de negatividade serão constitutivas nesse novo pensamento sobre a língua, e para isso, 
podemos destacar uma passagem do Curso, onde Saussure propõe exatamente esse corte:

[...] em lugar de ideias dadas de antemão, valores que emanam do sistema. Quando se diz que os valores correspondem a conceitos, subentende-se que são puramente diferenciais, definidos não positivamente por seu conteúdo, mas negativamente por suas relações com os outros termos do sistema. Sua característica mais exata é ser o que os outros não são (SAUSSURE, 2012, p. 164).

Esse corte epistemológico com as teorias tradicionais - não apenas as de Platão e Aristóteles - tem uma profunda influência na maneira de se enxergarem os significados, bem como a tradução: além de refutar a hipótese de que um significado se justifique por si mesmo, conforme a tese naturalista, há aqui a ideia de língua como pensamento organizado, como sistema, onde significante e significado são indissociáveis e constituídos pelo que Saussure chama de fato social: "A coletividade é necessária para estabelecer os valores cuja única razão de ser está no uso e no consenso geral" (ibidem, p. 132). Realçando o aqui mencionado, podemos citar Jost Trier, no intuito de entender o motivo pelo qual traduzir, então, seria tão difícil que todo tradutor seria um traidor:

Cada língua constitui um sistema que opera uma seleção através e às expensas da realidade objetiva. Na verdade, cada língua cria uma imagem da realidade, que é completa e se basta a si mesma. Cada língua estrutura a realidade à sua própria maneira e, por isso mesmo, estabelece os elementos da realidade que são peculiares a essa determinada língua. Os elementos de realidade da linguagem numa língua determinada nunca reaparecem exatamente sob a mesma forma numa outra língua e nem constituem uma cópia direta da realidade (TRIER apud MOUNIN, 1975, p. 51).

Em sua obra, Paulo Britto, apesar de defender a fidelidade de uma tradução ao seu original, a ponto de que o leitor afirme, por exemplo, ter lido Kafka, mesmo só tendo tido acesso a uma tradução da obra original, também reconhece a dificuldade, e mais além, a impossibilidade, de uma tradução absoluta: "A delimitação entre os conceitos próximos, dentro de um mesmo campo semântico, se faz de modo diferente em línguas diferentes"; e prossegue, "Às vezes uma palavra que existe num idioma simplesmente não encontra correspondência em outro, muito embora a realidade a que ambos se referem seja a mesma". Portanto, seria impossível que uma tradução conseguisse, ipsis literis, retratar a realidade de uma língua traduzindo-a para outro idioma, apesar de isso fazer parte de um senso comum nos meios sociais onde não se tem a menor ideia do que realmente seja traduzir. Contudo, vemo-nos diante de outro mito, este por parte de alguns tradutores profissionais: o de que traduzir é uma tarefa tão complicada que chega a beirar o impossível. Angela Levy enumera as qualidades ideais de um tradutor "simplesmente bom", quais sejam, "conhecimento perfeito das línguas de chegada" - será que esse conhecimento perfeito seria possível? - "conhecimento profundo das línguas de partida e bons conhecimentos da cultura, história, literatura, tradições e realidade presente dos povos com cuja língua vão trabalhar”. Não suficiente, 
Levy ainda sugere como imprescindíveis características pessoais como "ser meticuloso mas dinâmico, pacientes mas rápidos e autoconfiantes mas conscienciosos, além de donos de um enorme senso de responsabilidade e honestidade profissional". Parasse por aqui, a tarefa de se achar um bom tradutor já me pareceria ingrata, entretanto Levy vai adiante, o que nos dá uma impressão de que do outro lado também existe a construção de um mito: o do tradutor-cyborg: traduzir é uma tarefa tão ciclópica que qualquer pessoa não poderia se arriscar a prestar este ofício, até porque, nas palavras de Levy, o aprendizado da arte de traduzir é uma questão de "dom”.

A questão mais importante é que, em ambos os mitos - seja no "traduzir é fácil", seja no "traduzir é tarefa para poucos" - há a sustentação da visão tradicional de língua: aquela que possui uma verdade por detrás de suas letras, de seu significante. Enquanto os primeiros desmerecem a atividade tradutória pelo simples fato de considerarem que traduzir é buscar um significado que está em algum lugar "encontrável" dentro da palavra ou do texto, os últimos, ao afirmar que traduzir é tarefa impossível, devido às diferenças culturais e sociais de cada língua, ratificam a ideia essencialista de verdade, contudo, somente divergem por não considerarem essa verdade palpável: para estes, ela é quase que inalcançável.

\section{4) Outras considerações}

Analisando os dois vieses mencionados, acerca dos mitos da tradução, pode-se inferir que, tanto para aqueles que corroboram a ideia de que traduzir seja tarefa simplória, quanto para os que apregoam a super-tradução, tarefa para super-homens, possuem o mesmo referente quanto ao assunto: para ambos, existiria em algum lugar a chamada tradução legítima, perfeita, aquela que alcança a estabilidade presente no texto, a única diferença seria que, para os primeiros, esse objetivo é plenamente alcançável se se buscar a essência das palavras, e, para os últimos, essa tradução seria impossível. Podemos visualizar essa impossibilidade, por exemplo, após as ideias saussureanas de línguas como sistema, cujo conjunto de valores são frutos de uma rede relacional e diferencial entre seus elementos, e, ainda, conforme as teorias neohumboldtianas citadas por Mounin, onde essas redes são diferentes em cada língua, nunca reaparecendo de igual forma, negando-se, então, qualquer possibilidade de alguma tradução, ou, pelo menos, de demonstrar a equivalência traducional entre suas dadas línguas (MOUNIN, 1975, p. 56). A metáfora saussureana do papel problematiza, de certa forma, a tradução total, apregoada pela tradição, ao dizer que

A língua é comparável a uma folha de papel: o pensamento é o anverso e o som o verso; não se pode cortar um sem cortar, ao mesmo tempo, o outro; assim tampouco, na língua, se poderia isolar o som do pensamento, ou o pensamento do som (SAUSSURE, 2012, p. 159). 
Essa questão, sob a visão pós-estruturalista, não cessa de se problematizar, mas é abordada com mais flexibilidade:

Toda tradução, por mais simples e breve que seja, trai sua procedência, revelas as opções, as circunstâncias, o tempo e a história de seu realizador. Toda tradução, por mais simples e breve que seja, revela ser produto de uma perspectiva, de um sujeito interpretante e, não, meramente, uma compreensão neutra e desinteressada (...) (ARROJO, 2003, p. 67).

Aqui se refuta o ideário logocêntrico que ainda habita muitos conceitos sobre tradução: para Rosemary Arrojo não há um resgate de sentido "certo" ou "errado" dos significados presentes nos textos traduzidos, hipoteticamente estáveis, a-históricos e fixos, à espera de alguém que os alcance. A tradução é sempre possível, como bem afirma Paulo Britto, mas foge dos juízos de valores concedidos pela metafísica. Não pode haver uma objetividade suprema, tampouco uma subjetividade excessiva no ato tradutório, há sim que se reconhecer a necessidade de que a fidelidade ao original é possível, mas nunca perfeita, pois fatores relativos ao sujeito, suas ideologias, não escapam ao texto, conforme admitem Rajagopalan e Arrojo:

[...] se não podemos encontrar nenhum significado desatrelado de um interesse ideológico e de uma perspectiva, e se é a partir desses significados ideologicamente marcados que produzimos não apenas a leitura de qualquer texto mas também as formas e as características de qualquer instituição; ou seja, se em última análise cabe ao homem esse poder de criar significados e instituições, é, no mínimo, justo que esse jogo seja apresentado como tal" (RAJAGOPALAN \& ARROJO, 2003, p. 90)

e não mais como um jogo de caça à verdade em detrimento da mentira, como tanto enfatizou a teoria logocêntrica.

\section{5) A Linguística saussuriana e suas contribuições para a tradução}

O Curso de Linguística Geral, de Ferdinand de Saussure, ao focar a langue como seu objeto de estudo, em detrimento da parole, traz consideráveis avanços para a teoria linguística, mesmo que, ao relegar o sujeito e tudo o que ele evoca (cultura, sociedade, história, etc.) a um plano de somenos importância, venha a ser passível de críticas nesse sentido. Conforme o próprio Saussure afirma em sua obra, a língua não é mera representação de um exterior, ou um repertório lexical pronto para a mimetização do mundo lá fora: a grande revolução saussuriana é dar à língua um caráter sistêmico, cuja ordem ocorra não em função de um universo metafísico, mas sistematicamente, dentro da própria língua:

Cumpre acrescentar uma faculdade de associação e de coordenação que se manifesta desde que não se trate mais de signos isolados; é essa faculdade que desempenha o principal papel na organização da língua enquanto sistema (SAUSSURE, 2012, p. 44). 
Ao abalar, de certa forma, a noção representacionista de linguagem, introduzindo-a como um sistema, Saussure desfigura também a maneira de conceber a prática tradutória como transposição de palavras em línguas diferentes, como a fórmula descrita por Mounin onde "a tradução consistia em escrever que: a, b, c, d...=A, B, C, D.../ $a^{\prime}, b^{\prime}, c^{\prime}, d^{\prime} \ldots=A^{\prime}, B^{\prime}, C^{\prime}, D^{\prime} . . /$ de modo que: $a, b, c, d \ldots=a^{\prime}, b^{\prime}, c^{\prime}, d^{\prime} . .$. (MOUNIN, 1975, p. 49), - modelo esse criticado pelos neo-humboldtianos, conforme vimos anteriormente, embrionário da crença comum sobre tradução como uma ação simples e fácil. Saussure, ao desenvolver a noção de valor dentro do sistema linguístico, "bagunça" o ideário tradicional de linguagem, propondo que, em certas línguas do mundo, não há sequer elementos semanticamente equivalentes entre si, o que poderíamos dizer - põe em risco o ato de traduzir. Segundo Maria Paula Frota, "a linguística estruturalista veio embasar cientificamente a crença na intraduzibilidade, e a ampliar o seu escopo" (FROTA, 2000, p. 51), e em muitas passagens do Curso podemos visualizar esse recorte saussuriano:

O português carneiro ou o francês mouton podem ter a mesma significação que o inglês sheep, mas não o mesmo valor, isso por várias razões, em particular porque, ao falar de uma porção de carne preparada e servida à mesa, o inglês diz mutton e não sheep. A diferença de valor entre sheep e mouton ou carneiro se deve a que o primeiro tem a seu lado um segundo termo, o que não ocorre com a palavra francesa ou portuguesa. [...] $\mathrm{O}$ que se disse das palavras aplica-se a qualquer termo da língua, por exemplo às entidades gramaticais (SAUSSURE, 2012, p. 162-163).

Os impactos que a Linguística de Saussure exerce sobre a prática tradutória são imensos, e, ao passo que deserda o tradutor de um universo essencialista, cujas palavras possuem um sentido positivo em sua natureza - conforme visto nas primeiras linhas deste trabalho, ao sublinharmos o Crátilo - insere-o dentro de um sistema fechado, homogêneo e estável, mas que difere de língua para língua, pois "o conhecimento de línguas/signos diferentes passa a implicar o conhecimento de mundos e de categorizações conceituais possivelmente distintos, de valores, portanto, possivelmente diversos" (FROTA, 2000, p. 51).

\section{6) A problemática da intraduzibilidade}

Diante de um cenário em que traduzir se configurava tarefa impossível, logo ilegítima, para o qual tanto a teoria saussuriana como o estruturalismo colaboraram de uma forma geral, os pós-estruturalistas perceberam que essa visão sobre a tradução não diferia muito da tradicional, visto que, conforme já dissemos, ambas consideravam a existência da tradução perfeita, da tradução total: enquanto para os estruturalistas a essência do que seria "a tradução" era incapturável, para os tradicionais essa essência era o norte a ser seguido. Os pós-estruturalistas, ao contrário dos estruturalistas, 
considerarão a tradução uma prática completamente possível, afinal, ela está aí, acontece, obras de todo o mundo, de "n" línguas diferentes, são traduzidas para se sabe lá quantas outras, e não há como se dizer que a tradução seja impossível ou ilegítima. $\mathrm{O}$ que se refuta aqui é a possibilidade da tradução total, a existência de hierarquias entre original e tradução, a quebra da dicotomia autor/tradutor, de forma que a subjetividade de quem traduz possa ser levada em conta e inscrita no seu ato de leitura/tradução.

O Autor-Deus - logo a Obra-Deus - não comparece na compreensão pósestruturalista de linguagem, para a qual a impossibilidade gira em torno da crença de que tenhamos as mesmas afecções animísticas, por mais que difiram nossas fala e escrita; entretanto, não é pelo fato de não termos as mesmas paixões, de vivermos sistemas linguísticos diferentes, que traduzir seja algo impossível. Os conceitos derridianos de diférrance, écriture, bem como sua proposta do duplo gesto, ser-nos-ão de enorme valia para compreendermos onde esses pensadores rompem com o modelo de língua saussuriano, e até que ponto levam-no às últimas consequências.

\section{1) Críticas à Linguística saussuriana}

Algumas suposições dicotômicas feitas por Saussure, tais como langue/parole, sincronia/diacronia, significado/significante, onde o primeiro elemento sempre subordina o segundo, foram objeto de crítica dos pós-estruturalistas, principalmente por Jacques Derrida, segundo a afirmação de Culler (1997):

Em oposições tais como sentido/forma, alma/corpo, intuição/expressão, literal/metafórico, natureza/cultura, inteligível/sensível, positivo/negativo, transcendente/empírico, sério/não-sério, o termo superior pertence ao logos e é uma presença mais elevada; o termo inferior sinalizada uma queda. Assim, o logocentrismo supõe a prioridade do primeiro termo e concebe o segundo em relação a ele, como uma complicação, uma negação, uma manifestação ou ruptura do primeiro (p. 107-8).

Ao propor o duplo gesto, Derrida, primeiramente, inverte o binarismo, priorizando, por exemplo, o significante ao significado; e, por fim, seu segundo gesto é fazer implodir um elemento no outro, a fim de que, sendo coisas diferentes, sejam a mesma coisa: relações coordenadas em vez de subordinadas, um jogo "livre" de significantes em detrimento de um significante atrelado a um significado - como uma folha de papel, consoante escreveu Saussure. Através de um duplo gesto, uma dupla ciência, uma dupla escrita, Derrida põe em prática uma "reversão da oposição clássica e uma substituição geral do sistema" (Ibid., p. 100). Sua diférrance remeterá exatamente a esse adiamento do ponto de parada do significante, protelando o vértice onde se fundem as comparações paradigmáticas, o que, necessariamente, remexe com as noções clássica e estruturalista 
sobre tradução, pois aqui é o tradutor/leitor quem escreve e se inscreve em cada texto do qual é sujeito, não mais objeto. Seu conceito de écriture forja uma prática tradutória que, remetendo a Tlön - o planeta borgeano - concede à tradução o poder de ser também um original, pior ou melhor do que esta: um "mesmoutro".

\section{2) A retomada pós-estruturalista a Saussure}

Por outro lado, os pós-estruturalistas veem em Saussure uma virada conceitual de grande relevância para os estudos linguísticos: ao falar da língua como um sistema cujos signos possuem características negativas e diferenciais, há um corte epistemológico valioso com a teoria positiva da palavra, a qual possuía um sentido pleno inerente à sua natureza; com a substantividade do signo - decorrente da afirmativa de Saussure a qual mostra que "a Linguística trabalha, pois, no terreno limítrofe em que os elementos das duas ordens [pensamento e som] se combinam; essa combinação produz uma forma, não uma substância" (SAUSSURE, 2012, p. 160) - em prol da relacionalidade do mesmo com outros elementos de seu sistema; e com o modelo de língua-repertório já mencionado, em nome de signos arbitrários e convencionais, de modo que cada um deles não seja definido por uma propriedade essencial, mas pelas diferenças que os distinguem de outros signos. Todas essas inovações saussurianas serão levadas às últimas consequências pelos estudiosos pósestruturalistas, que procurarão desvencilhar essas ideias de uma cadeia fechada de raciocínio e trazê-la para a linguagem como práxis.

Se Saussure afirmou que a negatividade do signo só se dá com significante e significado tomados separadamente, como podemos ver na citação que segue:

Mas dizer que na língua tudo é negativo só é verdade em relação ao significante e ao significado tomados separadamente: desde que consideremos o signo tomado em sua totalidade, achamo-nos perante uma coisa positiva em sua ordem (SAUSSURE, 2012, p.168),

pós-estruturalistas dirão que a incidência da negatividade vai muito além. Citando outra feita Derrida, temos que:

O jogo de diferenças envolve sínteses e referências que evitam que haja, em qualquer momento ou de qualquer modo, um simples elemento que esteja presente em e por si mesmo e que se refira apenas a si próprio. Seja no discurso escrito ou falado, nenhum elemento pode funcionar como signo sem se relacionar a outro elemento, que por sua vez não está simplesmente presente. Essa ligação significa que cada 'elemento' fonema ou grafema - é constituído com referência ao vestígio que contém de outros elementos da sequência ou sistema (DERRIDA, 1981, p. 37-38). 
Ao dispor da substancialidade do signo pela noção de arbitrariedade, bem como a do valor, Saussure e os pós-estruturalistas se convergem em prol de uma linguagem liberta das algemas do representacionismo clássico, pois "é a noção de valor que justamente consiste no principal baluarte da diferença e da negatividade, opondo-se à ideia de signo como um elemento portador de uma identidade própria, isolada e definitiva" (FROTA, 2000, p. 46). E que impactos isso traz para uma reflexão acerca da tradução? Podemos dizer que a teoria do valor de Saussure radicalizada pelos pós-estruturalistas, além de rechaçar a imagem de que traduzir é fácil, não compartilha da posição estruturalista de que seja tarefa inviável. Com a desconstrução das dicotomias logocêntricas, das essências por trás do léxico, bem como a subversão da crença na incompatibilidade entre sistemas linguísticos, da preferência pelo significante e da inserção do sujeito como elemento ativo na tradução, o pós-estruturalismo valida e legitima o ato tradutório como uma nova escritura, onde tradutor e autor passam a ser nomenclaturas que se esvaem e se perdem nos desvãos de uma nova leitura, a qual também é uma nova escritura, e assim por diante.

\section{7) Signo lacaniano $x$ signo saussuriano}

Dentro desse cenário de rompimento com a tradição clássica, no que concerne à concepção de linguagem, à negação das dicotomias já vistas e à exclusão do sujeito da ciência, Sigmund Freud constrói a sua psicanálise priorizando elementos classicamente subordinados dentro dos binarismos tradicionais e pondo em xeque os pares binários significado/significante, sujeito consciente/sujeito inconsciente e, vanguardeiramente, normal/patológico. Com o advento do inconsciente, o qual, segundo sua ciência, exerce uma função de poder sobre o consciente, por meio dos erros, dos atos falhos, dos esquecimentos e dos lapsos de fala, leitura e escrita, a própria noção de tradução é abalada e modificada:

A psicanálise sem dúvida mantém uma relação ainda mais profunda com a tradução, na medida em que ela interroga a relação do homem com a linguagem, com as línguas e com a língua dita "materna", de uma maneira fundamentalmente diferente daquela da tradição (BERMAN apud FROTA, 2000, p. 137).

Freud, ao considerar a linguagem do inconsciente, amplia o universo tradutório. Se Nietzsche disse, certa feita, que o homem é um animal metafórico, afirmo que Sigmund nos conduz à certeza de que o homem é um animal tradutor. Consoante seus estudos, o inconsciente possui em seu bojo uma linguagem diferente daquela com a qual estamos acostumados em nosso dia a dia. Ela não pode ser transmutada simplesmente para as línguas maternas que possuímos, pois, tais como as palavras primitivas e os sonhos, o inconsciente fala mais de um dialeto, e "de acordo com as diferentes condições psicológicas que orientam e distinguem as diversas formas de neurose, encontramos modificações regulares na maneira pela qual os impulsos mentais 
inconscientes se expressam" (FREUD, 1970, p. 161), e n'A Interpretação de Sonhos, Freud reafirma a dificuldade de se traduzir essa linguagem confusa para o consciente:

O modo pelo qual os sonhos tratam a categoria de contrários e contradições é bastante singular. Eles simplesmente a ignoram. O "não" parece não existir, no que se refere aos sonhos. Eles mostram uma preferência particular para combinar os contrários numa unidade ou para representá-los como uma e mesma coisa. Os sonhos tomam, além disso, a liberdade de representar qualquer elemento, por seu contrário de desejo; não há, assim, maneira de decidir, num primeiro relance, se determinado elemento que se apresenta por seu contrário está presente nos pensamentos do sonho como positivo ou negativo (FREUD, 1976, p. 271).

Assim, através da psicanálise freudiana, vemos que o circuito da fala descrito por Saussure não é algo tão pacífico assim, naturalmente ocorrido, como se os trabalhos psíquico, fisiológico e físico acontecessem sem intervenções de qualquer elemento que pudesse por em risco a comunicação consciente entre falantes. Para Freud, a linguagem psíquica é resultado de um trabalho tradutório das imagens inconscientes, e o caminho desta até a fala ou a escrita envolve processos de re-tradução.

A psicanálise de Lacan talvez nos faça entender melhor como esses adventos científicos influem na linguagem de signos comportada por nós. Lacan, tomando como referência o signo saussuriano, representado pela imagem:

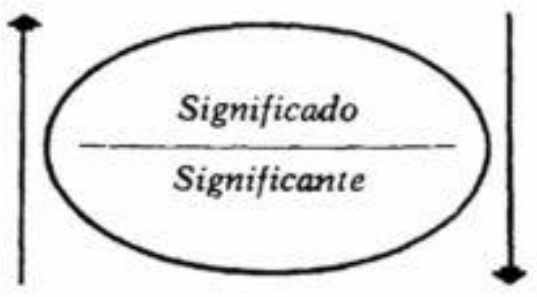

inverterá a posição dos elementos do signo, de forma que o significante passe a ocupar um lugar prioritário em relação ao significado, de forma que o "S" representativo do significante seja maiúsculo em face do "s" minúsculo do significado; em vez de uma linha fina e tênue separando os elementos do signo, Lacan propõe uma barra espessa, a qual marca a separação entre ambos, ao invés de uma ligação indissociável entre eles; o apagamento das setas indicando que a relação entre os elementos do signo não se resume à biunivocidade; a eliminação da elipse para demonstrar que a relação entre ambos não é fechada. Destarte, o signo lacaniano fica desta forma representado: 


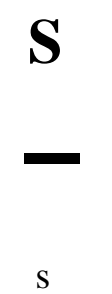

Quanto a essas características do signo lacaniano em oposição ao saussuriano, Maria Paula Frota nos esclarece as principais diferenças:

O significante, S, acima da barra sugere sua primazia relativamente ao significado, s, o que parece ser reforçado pelo "s" maiúsculo em contraposição ao minúsculo. A barra, acentuada por Lacan através de uma traço mais forte, marca a separação entre os dois, separação da qual Saussure, como vemos a seguir, acaba por abrir mão: "mas dizer que na língua tudo é relativo só é verdade em relação ao significante e ao significado tomados separadamente [...]" (Curso, 1975:139). Além de marcar a autonomia do significante em relação ao significado, a maior espessura da barra simboliza a resistência que ela oferece à passagem do plano do significante ao plano do significado, favorecendo o remetimento (sintagmático ou metonímico) de um significante aos outros significantes da cadeia, a significação só sendo produzida enquanto efeito do jogo retroativo de um remetimento de um significante a outro (v. Balbi, 1984:70). O apagamento das flechas confirma a resistência que a barra enfatizada apresenta à significação (Lacan, 1978b: 227-8), na medida em que sugere o apagamento da relação biunívoca entre determinado significante e determinado significado, proposta no Curso. Finalmente, a supressão da elipse parece mostrar muito bem que, dissociados, significante e significado deixam de formar uma unidade fechada (FROTA, 2000, p. $67)$.

Tendo em vista as inovações linguísticas trazidas pela psicanálise, tanto a freudiana quanto a lacaniana, por intermédio dela percebemos que tanto o sujeito da langue - apagado e conduzido pela sistematicidade da língua, presente em algum lugar de sua psique - como o sujeito da parole - senhor de si e da linguagem, conscientemente manipulador dos processos e produtos de sua comunicação - são insatisfatórios, dentro de um ponto de vista psicanalítico e pós-estruturalista. Primeiramente, como muito já se falou neste trabalho, o sujeito da langue nos remete a um sujeito amarrado, preso às impossibilidades que as línguas diferentes se lhe apresentam, no que atine à prática tradutória, por exemplo. E o sujeito da parole nos conduz a um erro de cálculo quanto às possibilidades que este pode atingir: não se percebendo como sujeito de linguagem, ignora seu assujeitamento a ela e torna-se presa inocente dos lapsos impostos pela força do inconsciente que, encadeando significantes como no caso da aluna Maryluci, ao traduzir um poema de Sylvia Plath (Kindness) deparou-se com o correspondente "colando" para "picking up", em vez de "catando" ou "pegando" (FROTA, 2000, p. 204) - exerce sobre ela "uma força maior no que diz respeito aos sentidos que provocou em sua leitura, do que ao aspecto propriamente 
material da cadeia. Tais associações de sentido Freud denomina pontes associativas" (Ibid.).

Essas novas ideias acerca do sujeito trouxeram uma crise no conceito de autoria, pois, como se falar em um autor para determinado texto se esse, assujeitado à linguagem, também é sobredeterminado por diversos fatores, por outras leituras, por outras consciências, por seu inconsciente? A posição teológica em relação a sua produção textual, oral e psíquica que a tradição lhe garantiu, inicia sua derrocada, conforme vemos em citação de Arrojo a Freud:

Em sua relação com o id, o ego é como um cavaleiro que tem de manter controlada a força superior do cavalo, com a diferença de que o cavaleiro tenta fazê-lo com a sua própria força, enquanto que o ego utiliza forças tomadas de empréstimo. Com frequência, um cavaleiro, se não deseja ver-se separado do cavalo, é obrigado a conduzi-lo onde este quer ir; da mesma maneira, o ego tem o hábito de transformar em ação a vontade do id, como se fosse sua própria (FREUD apud ARROJO, 2003, p. 1314).

Ainda em Roland Barthes:

Sabemos agora que um texto não é feito de uma linha de palavras, libertando um sentido único, de certo modo teológico (que seria a "mensagem" do Autor-Deus), mas um espaço de dimensões múltiplas, onde se casam e se contestam escritas variadas, nenhuma das quais é original: o texto é um tecido de citações, saídas dos mil focos da cultura (Barthes, 2004, p. 04).

\section{7) Considerações finais}

Por último, considero interessante trazer o conceito lacaniano de lalangue, a fim de confrontarmo-lo com a langue de Saussure e verificar quais as implicações do primeiro na tradução.

Já se falou neste trabalho que, na visão de Saussure, a língua possuía essa característica homogênea, sendo "um objeto bem definido no conjunto heteróclito dos fatos da linguagem" (SAUSSURE, 2012, p. 46), inteiramente alheia ao indivíduo, de forma que este seja impossibilitado de modificá-la ou criá-la. A psicanálise, especialmente com Lacan, redefinirá o lugar dessa langue, sem negá-la, entretanto colocando-a como um suporte do que este chamará lalangue: a capacidade intrínseca de gerar equívoco em seus registros, de dizer o que escapa à consciência do falante, de manifestar o desejo do inconsciente, em suma, de embaralhar o conceito estável e intocável de langue, mostrando como a cadeia de signos constitui o sujeito e, concomitantemente, é dele efeito: 
É por considerar que dois sujeitos não podem se reunir, tornar-se um; por considerar que são discerníveis e não simetrizáveis, que a psicanálise critica a noção de língua como puro instrumento de comunicação, o seu uso como troca tranquila de mensagens entre parceiros homogêneos e simétricos. Para a psicanálise, em toda língua há um registro que a consagra ao equívoco; em todo discurso pode-se fazer valer uma dimensão do não-idêntico e tudo que o promove: "homofonia, homossemia, homografia, tudo o que suporta o duplo sentido e o dizer em meias-palavras, incessante tecido de nossas conversações" (v. Milner, 1987:62). É a esse registro do equívoco, do não-todo, ignorado pela Linguística que Lacan dá o nome de alíngua (FROTA, 2000, p. 64).

Essa transformação feita por Lacan ao signo saussuriano implica uma ruptura com os padrões clássicos de se praticar e de se enxergar a prática tradutória, na medida em que abdicamos da possibilidade de neutralidade por parte do tradutor, este cônscio de seu assujeitamento à linguagem, sendo afetado por ela e afetando da mesma forma o texto de partida. Encerro este artigo com mais uma citação de Maria Paula Frota, que vem ao encontro dessa ruptura causada pela lalangue na visão tradicional de tradução:

Poder conceber como significantes palavras que se apresentam à leitura e não necessariamente como signos, e os textos, da mesma forma, como cadeia de significantes e não mais de signos provoca uma ruptura definitiva com as visões tradicionais de tradução. Abre-se espaço a sentidos engendrados de modo singular na leitura, pelo tradutor, do texto de partida. Esses sentidos constituir-se-iam enquanto efeito do jogo entre significantes operado no sujeito tradutor (este também reconcebido). Os efeitos conscientes e inconscientes desse jogo é que norteariam o processo de escrita do texto traduzido, e não mais o chamado original - este, tradicionalmente tomado como objeto semanticamente já constituído e a ser preservado, feitos os ajustes formais necessários, na língua de chegada (ibidem).

\section{8) Referências bibliográficas}

ARISTÓTELES. Órganon: Da interpretação. Bauru: Edipro, 2005.

ARROJO, Rosemary. O signo desconstruído: Implicações para a tradução, a leitura e o ensino. $2^{\text {a }}$ Edição. Campinas/SP: Ed. Pontes, 2003.

BARTHES, Roland. A morte do autor. In O rumor da língua. Lisboa: Edições 70, 1984.

BRITTO, Paulo H. A Tradução Literária. $1^{\text {a }}$ Edição. Rio de Janeiro: Civilização Brasileira, 2012.

CULLER, Jonathan. Sobre a desconstrução. Trad. Patrícia Burrowes. Rio de Janeiro: Ed. Rosa dos Tempos, 1997. 
DERRIDA, Jacques. Positions. Paris: Minuit, 1972. Tradução para o inglês: Chicago : University of Chicago Press, 1981.

FREUD, Sigmund. A interpretação dos sonhos (1900). ESB. Rio de Janeiro: Imago, 1976.

A significação antitética das palavras primitivas. In Edição Standard Brasileira das Obras Psicológicas Completas de Sigmund Freud. Vol. XI. Rio de Janeiro: Imago, 1970.

FROTA, Maria Paula. A singularidade na escrita tradutora: linguagem e subjetividade nos estudos da tradução, na linguística e na psicanálise. Campinas/SP: Pontes, 2000.

LEVY, Angela. Sabe inglês? Vire tradutor... Boletim da ABRATES - Associação Brasileira de Tradutores, ano 1, n. 5, julho/setembro de 2001.

MOUNIN, Georges. Os problemas teóricos da tradução. Trad. de H. de Lima Dantas. São Paulo: Cultrix, 1975 (1963).

SAUSSURE, Ferdinand. Curso de Linguística Geral. 34 a Edição. São Paulo: Editora Cultrix, 2012.

SIMCOVICH, Rut. The Professional image of translators and interpreters. The ATA chronicle - a publication of the American Translators Association, v. XXXI, n. 4, April, 2002. 